\title{
Pedagogical means of students training in conditions of agricultural complex digitalization
}

\author{
Oksana N. Berishvili, Svetlana V. Plotnikova, Dmitry V. Romanov*, and Timur V. Filatov
}

Samara State Agrarian University, 446442 Kinel, Samara region, Russia

\begin{abstract}
The actual problem, and simultaneously, the trend of today's vocational education digitalization of agricultural experts training in Russia are investigated. The review of the theory of the question, which proves the idea of accord of vocational training digitalization process of the XXI century tasks, is made. Didactic digitalization elements as a process are correlated with the revealed professional agricultural engineering problems. Digitalization maintenances opportunities of science subjects as possible means of the priority purposes achievement of modern vocational trainings are investigated. The substantiation of the projected course «Methods of optimum decisions acceptance» as a set of the competence-focused modules is achieved, each of which corresponded to concrete type of optimization problems, solved by agroengineers in professional work.
\end{abstract}

\section{Introduction}

The driver of the present stage of the world social development provides an increase of economy efficiency and life quality improvement, transition to the digital information of all parties of economic and social life acts. The digital economy is a set of attitude, developing in processes of manufacture, distribution, exchange and the consumption based on online-technologies and directed for satisfaction of needs for the vital blessings [1] that assumes transformation of social and economic systems at all levels (state, branch, corporate).

The importance of the given trend of development of economy proves to be true initiated by the State Duma of the Russian Federation. More than 50 bills are connected with development of digital economy (crowd funding, use of block chain technologies, crypto currency, an artificial intellect, etc.). Development of the state program «Digital economy of the Russian Federation (the order of the Government of the Russian Federation dated July, 28th, 2017 № 1632-P), one of which directions is «the Digital agriculture».

As preconditions of branch digitalization we considered: great volume of data (an intensive stream of the information); need for innovative decisions which can be found on the basis of the digital information and can lead to optimization business of processes in branch, to reduction of charges and occurrence of new sources of branch incomes [3]. So, according to forecasts of the Department of Development and Management of the State Information Resources of Agrarian and Industrial Complex of the Ministry of Agriculture of Russia, highgrade use of opportunities of modern digital platforms for production management at macro-and local levels will allow one to raise efficiency of agricultural branches three-four times in the index expression [4].

It is marked that only complex application of technologies of exact agriculture (the parallel driving, the differentiated seeding, the differentiated application of fertilizers, etc.) will allow saving from 20 up to $40 \%$ of the means spent for these operations, in comparison with traditional methods of agricultural crops cultivation [5]. According to forecasts of experts, agricultural branch digitalization and the IoT-decision (Internet of Things) will bring total economic benefit at a rate of 4,8 bl. roubles a year or 5,6 \% of gross national product of Russia gain. Thus the volume of information technologies consumption can grow by $22 \%$ only due to only one branch digitalization - agriculture [6].

Scale transition to digital technologies has led to "personnel famine" - to deficiency of competences on digital transformation in all branches of economy. So, according to the analytical center, the Ministry of Agriculture of Russia shortage of IT-experts (adapted to agriculture) makes minimum of 90 thousand person [7] that is one of the basic deterrents in digital transformations to branches showing a problem of digital competence definition means formation of students (agroengineering), demanded in conditions of modern agriculture.

\section{Literature Survey}

The analysis of the scientific literature has revealed ambiguity of treatments of definition «digital competence» representatives of scientific and professional communities. They assured an effective utilization of information-communication technologies for work, rest, dialogue (L.V. Shmelkova). There is

Corresponding author: dmitrom@ rambler.ru 
ability to create and use a content by means of digital technologies, including skills of computer programming, search and information interchange, the communications with other people. There is a skill to work with a computer as "machine", understanding features of the device and distribution of the digital information, the device of network community and features of social media (G. Jenkins). This allows understanding a cultural context of the Internet-environment, the skill to communicate in online-communities, skill to create and distribute content, skills to use digital technologies for self-development (D. Belshou).

There is ability of the person to use digital information and communication technologies with the purpose of reception of access to the information, its managements, integration of the information, its testing and creations, and with the purpose of the communications. Thus, this allows observing ethical rules of law and, thus, the definition of ICT competence offered by the International advice on ICT-competence (International ICT Literacy Panel) [Educational Testing Service, 2002b] is high-grade to function in a modern society.

In L.V. Lapidus's opinion, the digitalization process of economy defines necessity of purchase of the following digital economy competences. They are systematized knowledge of digital economy, the nature of digital technologies and system transformations on micro, macro levels and global digitalization; hybrid trans-subjects administrative competence («technologies + economy»); administrative competence of development of social and economic models based on an optimum choice between competition and cooperation.

It is marked that for the leaders, special value will get the competence: ability to the organization of command work and synergetic effect achievement due to potential of collective reason. There is a skill of forming ecosystem activity in view of risks cyber security, duplications and synchronization of greater data, interoperability of used information systems [1]. For all categories of staff the key competences will become: analytical skills and work with greater data, creativity, flexible thinking, multi task ability [14].

According to data of the report «The Future of Jobs» (World Economic Forum), by 2020 there will be an increase in demand at critical thinking, creativity, emotional intelligence and cognitive availability [8]. The accent on development of these skills (abilities) becomes competitive advantage of the employee. Analysis of TOP-10 2020 competences in comparison with 2015 has shown that the important role in any kind of activity the competence «development and decision-making» (will play 8 and 7 positions in a rating, accordingly). In a context of our research that fact is of interest.

That one of the basic professional requirements to qualification of the engineer is readiness for conducting complex engineering activity and skill to apply theoretical and applied aspects of construction and development of mathematical methods and models of decision-making in dynamically changing conditions in professional sphere («Federation Europeenne d'Associations Nationales d'Ingenieurs, FEANI») [9].
Let us notice that the problem of decision-making researches has fundamental character that is defined by a role of the decision in any sphere of human activity. Decision-making concerns the number interdisciplinary as the choice of a way of actions is caused by a complex of various aspects (information, economic, logic, mathematical, organizational, psychological, technical and others) [10].

In philosophical understanding, decision-making is represented as the dialectical-materialistic process of knowledge going on a way of detection and overcoming of contradictions, and freedom of will - ability to make of the decision with skill (F. Engels).

In psychology decision-making is considered as a stage of the important certificate including such mental components, as the purposes, estimations, motives, installations, the form of interaction and cooperation between people, function of psychology of the person (L.S. Vigotskiy); the product of complex historical and ontogenetical developments during which its forms are varied (A.A. Utemisova). The psychological dictionary gives such definition to concept: "decision-making" is a certificate of actions sequence formation leading to achievement of the purpose based on transformation of the initial information in a situation of uncertainty [11].

In P.K. Anokhin's works the treatment of decisionmaking is given within the limits of functional system: «Decision-making is not isolated mechanism, isolated by the certificate, and one of stages in development of purposeful behaviour. It is impossible to carry out the decision in general, the decision which has been not included in any activity, not directed on any positive result» [12]

The questions connected with decision-making, are investigated in mathematical sciences (P.V. Konjuhovsky, N.SH. Kremer, V.A. Frolkis, etc.): decision-making is defined as search of the greatest or least (optimum) value of some function reflecting the purpose of management by system (criterion function). In pedagogics (L. Mann) decision-making is considered as the complex process including search and processing of the information for finding admissible variants.

A decision-making process in professional work (without dependence from its specificity) is defined by A.V. Karpov as any choice of one of alternative ways of an output from situations of uncertainty and its realization in performing actions of the subject. Thus, we come to conclusion that in each subject domain there is its own way of considered concept maintenances interpretation. Within the limits of our research, the process of decision-making is represented as a choice from a set of possible alternatives of an optimum way of an output from an uncertain (problem) situation in view of specificity and features of professional work [13].

The analysis of agriculture, agroengineer activity object, has revealed that in conditions of resources limitation (industrial, labour, raw, etc.) the problem of their optimization is analyzed. This key strategy of modern agrarian manufacture development in digitalization conditions causes the using of the optimum decisions in professional work acceptance. In this connection, we consider it expedient to add allocated 
earlier digital competence (base for experts in all branches of economy) with the competence of agricultural branch considering specificity - ability to accept in the future professional work methods of optimum decisions according to needs of agrarian manufacture.

\section{Methodology of research}

During this research, the methods of the theoretical analysis and synthesis of the scientific literature, empirical methods (the included supervision, questioning) were applied including qualitative and quantitative ways of the scientific information processing.

The practical importance, offers and results of introductions, results of experimental researches.

The analysis carried out during our research of agroengineering activity has allowed allocating the basic types of the optimization problems, solved in agrarian manufacture (table 1).

Statement and decision of optimization problems are an actual control facility agrarian manufacture in conditions of digitalization and an integral part of industrial-technological, organizational-administrative, research and design activity of agroengineers. Works of researchers (I.V. Aure, A.M. Berlyant, A.I. Martynenko, E.G. Kaprelov, N.V. Razumovskaja, I.V. Proletkin) testify to significant potential in realization of mathematical methods in management of agrarian manufacture.

At the same time it is revealed that methods of acceptance of the optimum decisions, allowing to define perspective directions of practical actions, an optimum variant of enterprise resources using, optimum organizational-economic and technical-technological decisions, in practice of agrarian manufacture, are not applied.

According to expert estimations, the process of decision-making is at an empirical-intuitive level: 32-35 $\%$ of decisions from the general number are accepted based on experience; $25-27 \%$ - on intuition; 3-5\% proceeding from a common position of the leader and only 30-35\% - based on the analysis of the facts [13].

There are a number of the reasons: complexity of preparation of the information, absence of practical skills of work with the specialized software and the mainabsence of the experts owning methods of decisionmaking.

The content-analysis results of degree projects of agricultural universities graduates has confirmed that increase of efficiency of agrarian manufacture, its modernization and reconstruction does not contact optimization of productions (619 messages are analysed, occurrence of a unit of measure - a word "optimization" - $0 \%$ ). The given fact speaks that in the agroengineering training curriculum, the subject «Methods of optimum decisions» and its possible updatings («Mathematical programming», «Methods of optimization», «Methods of operations research») are not included into the list of not only base and additional disciplines, but also disciplines at the choice of students.

Table 1. The problems of optimization, solved by agroengineers in professional work

\begin{tabular}{|c|c|}
\hline $\begin{array}{c}\text { Types of } \\
\text { optimization } \\
\text { problems }\end{array}$ & Agro engineer professional problems \\
\hline $\begin{array}{l}\text { Problem of } \\
\text { resource } \\
\text { distribution (the } \\
\text { equipment, raw } \\
\text { material, work } \\
\text { force, etc.) }\end{array}$ & $\begin{array}{l}\text { Choice of machine-tractor park structure } \\
\text { optimum, structure of agricultural units } \\
\text { and complexes of machines, } \\
\text { specializations of farms with an } \\
\text { optimum combination of branches; } \\
\text { optimum structure of seeding areas, } \\
\text { technology of crops cultivation }\end{array}$ \\
\hline $\begin{array}{l}\text { Problem of } \\
\text { storekeeping } \\
\text { (material, } \\
\text { monetary, etc.) }\end{array}$ & $\begin{array}{l}\text { Definition of optimum quantity of spare } \\
\text { parts, repair materials, mineral oil and } \\
\text { time of updating of the stock for } \\
\text { uninterrupted manufactured }\end{array}$ \\
\hline $\begin{array}{l}\text { Problem of } \\
\text { maintenance } \\
\text { service }\end{array}$ & $\begin{array}{l}\text { Choice of optimum terms of carrying } \\
\text { out of scheduled preventive and capital } \\
\text { repairs of machine-tractor, motor pool } \\
\text { and other means; replacement of the old } \\
\text { equipment by the new one }\end{array}$ \\
\hline $\begin{array}{l}\text { Problem of } \\
\text { planning and } \\
\text { accommodation } \\
\text { of objects }\end{array}$ & $\begin{array}{l}\text { Choice of an optimum route cargo } \\
\text { delivery }\end{array}$ \\
\hline $\begin{array}{l}\text { Problem of } \\
\text { enterprise and } \\
\text { its departments } \\
\text { management }\end{array}$ & $\begin{array}{l}\text { Drawing up of planned schedules; the } \\
\text { account of actual condition, the analysis } \\
\text { of deviation of the fact from the plan; } \\
\text { drawing up of tasks to executors for the } \\
\text { certain period; definition of } \\
\text { "unprofitable" works, time } \\
\text { characteristics of the project; } \\
\text { arrangement of various categories of the } \\
\text { personnel; choice of an optimum variant } \\
\text { of the plan providing performance of } \\
\text { works in set terms with the minimal } \\
\text { expenses }\end{array}$ \\
\hline $\begin{array}{l}\text { Problem of } \\
\text { enterprise } \\
\text { strategy } \\
\text { development in } \\
\text { conditions of } \\
\text { competition }\end{array}$ & $\begin{array}{l}\text { Development of enterprise strategic } \\
\text { plans in market conditions; an } \\
\text { estimation of enterprise strategy in } \\
\text { games with "nature" (for example, a } \\
\text { choice of sites of various fertility for } \\
\text { one of possible crops seeding in case of } \\
\text { authentic data about weather conditions } \\
\text { absence) }\end{array}$ \\
\hline
\end{tabular}

Besides the mathematical methods of research applied to the decision of real engineering problems, by virtue of complexity and great volume of calculations, demand use of information technologies. At the same time, in a rate «Information Technologies» for studying the processor Microsoft Excel, allowing to solve optimization problems, we allocated four study hours of employment (superstructures ToolPak and «Search of decisions» are not considered). Opportunities of specialized mathematical packages using (MathCAD, MatLAB, etc.) for the decision of optimization problems are not studied neither in "Mathematics", nor in «Information technologies».

Thus, the contradiction between necessity of use of methods of acceptance of optimum decisions for agroengineers professional work in conditions of economy digitalization and unavailability of students 
future agroengineers to their application is found out. One of ways of the sanction of the developed contradiction is development and introduction of integrated course (metasubject) «Methods of optimum decisions acceptance», directed to formation of digital competence - abilities to apply in the future professional work methods of optimum decisions according to needs of agrarian manufacture.

The projected metasubject «Methods of optimum decisions acceptance» is represented in the form of a set of the competence-focused modules, each of which corresponds to concrete type of problems of the optimization solved by agroengineers in professional work (table 1). Thus, training is carried out in a context of the future professional work. Thus educational problems are solved by means optimizing productions (i.e. training by means, which in the further will be used in professional work).

Modules of metasubject are represented in the form of sequence of blocks (the problem, theoretical block, applications, joining, generalizations), corresponding to the decision-making algorithm (revealing and the analysis of a problem situation, definition of strategy, choice of the best alternative, performance of the decision, estimation of decision efficiency). The competence-focused modules accustomed by means of case-method, promoting development of analytical, research, communicative skills, development of skills to analyze situation, to plan strategy and to make the decision (in our case - optimum decisions). As a result conditions for graduates adaptation to agroengineers activity are created, determined by conditions of digital economy and type of solved professional problems.

Skilled-experimental work has shown positive dynamics on all diagnosed parameters of formed competence that confirms legitimacy of pedagogical means choice.

\section{Conclusion}

The analysis of the scientific literature has revealed that occurring digital transformations of society economic and social life have caused the change of competences of development models, which are based on the systematized knowledge of the nature of digital technologies. During the research the list of competences, demanded in conditions of economy digitalization as a whole and agricultural branch in particular is certain. In conditions of agriculture digitalization the problem of its efficiency, increasing should be solved by modern methods of optimum decision acceptance. This is based methodology of mathematical modelling with realization of decisions in the information environment, whose competent application assumes presence of digital competence abilities to accept in the future professional work, the methods of optimum decisions according to needs of agrarian manufacture. The contradiction revealed during the research between the use of optimum decisions acceptance methods necessity for agro engineers professional work in conditions of economy digitalization and unavailability of students-future agroengineers to their application, has confirmed the necessity of actualization of higher education professional educational programs maintenance, choice of the pedagogical means adequate to needs of a digital agriculture. The received results can become the starting point for a system of engineering continuous branch experts training for digital economy, and designed metasubject «Methods of optimum decisions acceptance» designed as its substantial-remedial element.

\section{References}

1. L.V. Lapidus, E.M. Razumovskaya, I.A. Tarkhanov, Business Education Market in Russia: Current State and Development Outlook, Procedia - Social and Behavioral Sciences, 191, 391-395 (2015) DOI: 10.1016/j.sbspro.2015.04.390

2. The Program "Digital economy of the Russian Federation" (2017) Retrieved from: http://government.ru/docs/all/112831/

3. V.G. Halin, G.V. Chernova, Digitalization and its influence for the Russian economy and a society: advantages, calls, threats and risks, Administrative consultation, 10, 46-63 (2018) DOI: 10.22394/1726-1139-2018-10-46-63

4. I.S. Kozubenko, S.N. Kosogor, The influence of digital economy for development of agriculture, in Problems of management and modelling in complex systems, Mater. of XX Int. conf., 535-540 (2018)

5. I. Davletshin, A. Trofimov, Digital repartition. Advantages and risks of digitalization of agriculture, Retrieved from: https://www.agroinvestor.ru/ technologies/article/30405-tsifrovoy-peredel

6. Digitalization of agriculture in Russia: stages, results, plans, Retrieved from: https://geometerrussia.ru/a219060-tsifrovizatsiya-selskogohozyajstva.html

7. E.A. Skvortsov, E.G. Skvortsova, I.S. Sandu, G.A. Iovlev, Transition of an agriculture to the digital, intellectual and robotized technologies, Econ. of region, 14(3), 1014-1028 (2018) DOI: $10.17059 / 2018-3-23$

8. I.Z. Geliskhanov, T.N. Yudina, Digital Platform: A New Economic Institution, Quality - Access to Success, 19(2), 20-26 (2018)

9. A. Marej, Digitalization as change of paradigm, Retrieved from: https://www.bcg.com/ruru/about/bcg-review/digitalization.aspx

10. E.L. Vartanova, A.V. Vyrkovsky, M.I. Makseenko, S.S. Smirnov, Industry of Russian media: the digital future, monography (Moscow, 2017)

11. All about digital economy in Russia, Retrieved from: https://ruscoins.info/faq/cifrovaya-ekonomikav-rossii/ 
12. A.V. Keshelava V.G. Budanov, V.J. Rumjantsev, et al., Introduction in "Digital" economy (RSRIGeosystem, 2017)

13. O. Berishvili, N. Strekalova, A. Khramtsova. Key competences of industry professionals in the digital economy, in Int. Sci. and Pract. Conf. "Digital agriculture - development strategy” (ISPC 2019),
167, 77-79 (Atlantis Press, 2019) DOI: org/10.2991/ispc-19.2019.17.

14. D.V. Romanov, T.V. Filatov, Hirsh's index and the spirit of capitalism, Retrieved from: https://elibrary.ru/item.asp?id=36492862.

15. SHS Web of Conferences, 55, 03018 (2018) Retrieved from: https://elibrary.ru/contents. asp?id=36361793 